IZA DP No. 4877

Migration and Urban Poverty and Inequality in China

Albert Park

Dewen Wang

April 2010

Forschungsinstitut

zur Zukunft der Arbeit

Institute for the Study

of Labor 


\title{
Migration and Urban Poverty and Inequality in China
}

\author{
Albert Park \\ University of Michigan \\ and IZA \\ Dewen Wang \\ Chinese Academy of Social Sciences
}

Discussion Paper No. 4877

April 2010

IZA

P.O. Box 7240

53072 Bonn

Germany

Phone: +49-228-3894-0

Fax: +49-228-3894-180

E-mail: iza@iza.org

Any opinions expressed here are those of the author(s) and not those of IZA. Research published in this series may include views on policy, but the institute itself takes no institutional policy positions.

The Institute for the Study of Labor (IZA) in Bonn is a local and virtual international research center and a place of communication between science, politics and business. IZA is an independent nonprofit organization supported by Deutsche Post Foundation. The center is associated with the University of Bonn and offers a stimulating research environment through its international network, workshops and conferences, data service, project support, research visits and doctoral program. IZA engages in (i) original and internationally competitive research in all fields of labor economics, (ii) development of policy concepts, and (iii) dissemination of research results and concepts to the interested public.

IZA Discussion Papers often represent preliminary work and are circulated to encourage discussion. Citation of such a paper should account for its provisional character. A revised version may be available directly from the author. 
IZA Discussion Paper No. 4877

April 2010

\title{
ABSTRACT \\ Migration and Urban Poverty and Inequality in China
}

Using data from recent surveys of migrants and local residents in 10 cities in 2005, this paper examines how migration influences measurements of urban poverty and inequality in China, and also compares how other indicators of well-being differ for migrants and local residents. Contrary to previous studies that report that the income poverty rate of migrant households is 1.5 times that of local resident households, we find relatively small differences in the poverty rates of migrants and local residents. Although the hourly wages of migrants are much lower than those of local residents, migrant workers work longer hours and have lower dependency ratios and higher labor force participation rates. Including migrants increases somewhat measures of urban income inequality. Significant differences between migrants and local residents are found for non-income welfare indicators such as housing conditions and access to social insurance programs.

JEL Classification: J61, O15

Keywords: migration, urban, poverty, inequality, social protection, China

Corresponding author:

\author{
Albert Park \\ Department of Economics \\ University of Oxford \\ Manor Road Bldg. \\ Manor Road \\ Oxford OX1 3UQ \\ United Kingdom \\ E-mail: albert.park@economics.ox.ac.uk
}




\section{Introduction}

The issues of unemployment and poverty in urban China have aroused a lot of research interest in recent years. Prior to the 1990s, the urban poverty issue was trivial because state provision of jobs and housing, pension, and health insurance benefits were guaranteed for nearly all urban residents. In 1990, the number of the urban poor was estimated to be only 1.3 million, or 0.4 percent of the urban population (World Bank, 1992). During the 1990s, labor markets in urban China witnessed two important changes. First, widespread downsizing and closure of state-owned enterprises led to the layoffs of millions of urban workers, many of whom were not covered by government social assistance programs (Giles, Park, and Cai, 2005). Second, rural to urban migration increased dramatically, especially to large, coastal cities. The 2000 census found that 12.2 percent of the urban population were migrants. In cities (excluding townships), migrants accounted for 14.6 percent of the population and 19.6 percent of employed workers.

Recently, new estimates have been made of the extent of urban poverty in China. The estimated poverty rates have varied depending on the datasets used and the assumptions made in determining the poverty lines for different years. ${ }^{1}$ A common shortcoming of all of these studies

\footnotetext{
${ }^{1}$ World Bank (2009) reports a national urban income poverty headcount rate of 2.7 percent using a $\$ 2 /$ day poverty line and 9.7 percent using a \$3/day poverty line. Meng, Gregory, and Wang (2005) report an urban income poverty rate in 2000 of 1.7 to 4.0 percent using low and high lines calculated based on province-urban specific food bundles. Ravallion and Chen (2007) report a national urban income poverty rate of 0.54 percent in 2002 using a poverty line of 1200 yuan. Khan (1998) reports that urban poverty incidence increased by 12 percent from 1988 to 1995 using the China Household Income and Poverty Survey (CHIPS) data conducted by the Institute of Economics, CASS. The Asian Development Bank (2002) estimated that urban poverty incidence was 4.7 percent in 1998, but varied significantly among provinces. Based on the updated CHIPS data, Li (2001) calculated that the number of the urban poor was 23 million in 1999 with an incidence of 5.1 percent, and the poverty depth became more severe. The study group of the National Bureau of Statistics (NBS) estimated that the range of urban poverty incidence was from 4.4 percent to 5.8 percent with no clear trend in increase or decrease between 1991 and 1995 (Ren and Chen, 1996). New estimates of the National Bureau of Statistics (NBS) show that there was a slight reduction of urban poverty from 4.4 percent in 1995 to 3.4 percent in 2000 with the NBS poverty diagnostic line, which is about three
} 
is that they use data from surveys that exclude migrant households from the sampling frame. Most prominently, the National Bureau of Statistics' annual urban household survey does not systematically sample migrants. Large cities in many developing countries have large migrant populations that are poor, frequently living in slums and relying on the informal sector for employment. The United Nations Human Settlements Program (2003) predicted that absent new government interventions given current urbanization trends over the next 30 years one in every three people worldwide would live in urban slums characterized by poor public health, inadequate public services, and widespread violence and insecurity. Thus, exclusion of migrants from urban poverty and inequality measurement could lead to substantial bias.

A couple of recent studies have provided survey-based estimates of the poverty rate of both migrants and local residents. A recent report on urban poverty by the ADB uses data from a one-time survey conducted by NBS of 3600 migrants living in 26 provincial capital cities and 5 other cities (Dalian, Ningbo, Xiamen, Qingdao and Shenzhen) in 1999 to analyze the poverty situation of migrants (ADB, 2004; Hussain 2003). The report estimates an income poverty headcount rate of 15.2 percent for migrants compared to 10.3 percent for local residents using NBS annual urban survey data for the same cities. A recent study using data from the China Income Distribution Survey (CIDS) conducted in 2002 in collaboration with NBS in cities in 6 provinces estimates income poverty headcount rates of 3 percent for local residents and 10 percent for migrants using locally set poverty lines, and 6 percent for local residents and 16 percent between 2002 and 2004. 
percent for migrants using a higher poverty line (Du, Gregory, and Meng, 2006). ${ }^{2}$ However, in both of these surveys, incomes of local residents are based on self-recorded diaries used by NBS's annual urban household surveys while the incomes of migrants are based on one-time surveys that are known to produce lower income estimates. In addition, the local resident sample used by the ADB also excluded zero-income households and the CIDS surveyed only rural migrants, excluding urban migrants who are likely to have higher incomes. For all of these reasons, both studies are likely to overstate the poverty rate of migrants relative to local residents. These problems also mean that studies of urban-rural income gaps which also use the CIDS will underestimate urban-rural income gaps, or overestimate the effect of including migrants on reducing urban-rural differences. However, even with this bias, these chapters find that including migrants has a relatively small effect on measured urban-rural income differences.

In this paper, we analyze data from household surveys in 12 cities in 2004 and 2005 that use a common survey questionnaire and survey methodology for both migrants (including both rural migrants and urban migrants) and local residents. Contrary to previous studies that report that income poverty of migrant households is 1.5 times that of local resident households, we find relatively small differences in the poverty rates of migrants and local residents. Although the hourly wages of rural migrants are much lower than those of local residents, rural migrant households have lower dependency ratios and rural migrants have higher labor force participation rates and work longer hours. Including migrants does increase somewhat measures of urban income inequality. In contrast to poverty comparisons, significant differences between

\footnotetext{
2 The locally set poverty lines are minimum income per capita lines for obtaining urban dibao subsidy payments.
} 
migrants and local residents are found for non-income welfare indicators such as housing conditions and access to social insurance programs.

The rest of this paper is organized as follows. Section 2 describes the survey data. Section 3 presents measures of poverty incidence for migrants and local residents. Section 4 describes the characteristics of poor households. Section 5 examines income inequality. Section 6 examines non-income welfare measures, and section 7 concludes.

\section{Data}

In 2005, the Institute of Population and Labor Economics (IPLE) of the Chinese Academy of Social Sciences (CASS) conducted the second round of the China Urban Labor Survey (CULS) in 5 large cities $^{3}$ (all provincial capitals) in different parts of the country. The surveys were conducted in collaboration with faculty at the University of Michigan and Michigan State University, and supported by the World Bank. The CULS surveyed migrant and local resident households in each city. The 2005 CULS also surveyed migrants in 5 small cities located near the 5 large cities; in these small cities local resident households had been surveyed in the previous year by IPLE as part of the China Urban Social Protection survey (CUSP). ${ }^{4}$ The five large cities and five small cities are located in different regions of the country. Shanghai and Wuxi (Jiangsu Province) are located in the Yangtze River Delta near the coast; Wuhan and

\footnotetext{
${ }^{3}$ In this paper, we define capital cities as large cities and prefectural cities as small cities for simplification. According to this definition, there are 286 cities that include both prefectural cities and capital cities in 2005. Their population amounts 130.8 million, accounting for 19.4 percent of total urban population.

${ }^{4}$ Two additional cities also were included: Daqing, a city in Heilongjiang Province rich in oil resources, and Shenzhen, a city in Guangdong Province near Hong Kong, famous for its open labor market, large number of migrants, and private enterprise development. In this paper we restrict attention to the 5 large and 5 small cities.
} 
Yichuan are in Hubei Province in central China; Shenyang and Benxi are in Liaoning Province in the northeast; Fuzhou and Zhuhai are in Fujian and Guangdong provinces in the southeast; and Xian and Baoji are in Shaanxi Province in the northwest.

Table 1 summarizes some basic information on the 10 cities. The total population ranges from 6.6 to 13.5 million in the 5 large cities, and from 0.6 to 1.7 million in the 5 small cities. The average size of the total population in the 5 large cities is 8.5 million, or 7.4 times that in the 5 small cities. There is substantial variation in the level of economic development across cities, with coastal cities (Shanghai, Fuzhou, Wuxi, Zhuhai) having significantly higher per capita incomes.

In each city, representative samples of local residents and migrants were independently selected in a 2-stage procedure. Using recent data on the local resident population of each neighborhood, a fixed number of neighborhoods were selected in each city using probability proportionate to size (PPS) sampling. ${ }^{5}$ In each selected neighborhood, a sampling frame (list of households) was constructed in consultation with staff of neighborhood offices. Most neighborhood committees had complete, updated lists of local residents, and information on migrants who had registered as temporary residents. Neighborhood office staff also were aware of unregistered migrants living in the neighborhood, especially those operating small businesses. Using the constructed sampling frame for each neighborhood, a fixed number of households were randomly sampled in each neighborhood. In large cities, about 500 local resident

\footnotetext{
${ }^{5}$ In many cities, information was unavailable about the number of migrants living in each neighborhood. In such cases, neighborhoods were first selected based on local resident populations, and weights are used to correct for differences in the relative sizes of migrant and local resident populations using data on migrant population collected during the survey.
} 
households and 500 migrant households were sampled, and in the other cities the sample sizes were 400 or 500 of each type of household. In all, the survey collected data on 6324 local resident households and 5521 migrant households (See Table 1 for a detailed sampling breakdown).

For each household, information on each adult household member was collected on age, gender, education, marital status, party membership, type of hukou, health status, employment situation (wages, labor force participation, unemployment status, work history, and current job characteristics such as industry and occupation), access to social insurance (pensions, medical insurance, unemployment insurance), and education and training. The survey also collected household-level information on consumption expenditures, income transfers, social assistance, and housing conditions.

For the goals of this paper, the strengths of the CULS are that it surveys migrants (including rural migrants and urban migrants) and local residents in an identical fashion, it collects very detailed information on income and expenditure, and it collects enough observations per city to calculate city-level aggregates. At the same time, there are also several limitations of the data. First, for the 5 smaller cities, migrants were surveyed in 2005 while local residents were surveyed in 2004. Provincial CPIs are used to deflate all incomes to 2003 price levels, and an adjustment is made to account for mean real income growth in the five cities from 2004 to $2005 .{ }^{6}$ Second, by sampling migrants through neighborhood committees, it is

\footnotetext{
${ }^{6}$ In 2005, based on local government reports, the real growth rates of average disposable income were 17.8 percent in Wuxi, 7.9 percent in Yichan, 17.0 percent in Benxi, 7.9 percent in Zhuhai, and 10.0 percent in Baoji. We use these growth rates to adjust 2004 real urban household income to expected real income levels in 2005, implicitly assuming
} 
likely that migrants living in collective forms of housing, such as dormitories provided by work units, are under-sampled since such individuals typically do not register with local neighborhood committees. However, because migrants living in dormitories typically are employed and not living with dependents, they may be less likely to be poor, which would lead us to overstate the poverty rate of migrants in urban areas.

\section{Income poverty}

\subsection{Poverty line}

Unlike for rural poverty, in China there is no official government poverty line to measure urban poverty and there are no official estimates of the number of urban poor. However, as part of the government's minimum living standard (dibao) program, each city designates an income threshold, or dibao line, to determine whether households are eligible to receive government social assistance subsidies. In practice, richer cities tend to have higher dibao lines, either because they can afford them or because the lines reflect relative rather than absolute poverty. To create a uniform poverty line suitable for our purposes, we calculate a national mean dibao line by taking the population-weighted average of all dibao lines in China after first adjusting for spatial price differences using the indices calculated by Brandt and Holz (2005). As seen in Table 2, this line is equal to 1982 yuan per capita in 2003. It turns out that among our 10 cities, in only two cities (Yichan and Baoji) is the national mean dibao line larger than the actual dibao line.

We also consider 4 other poverty lines. The first is the official rural low income line

no change in the relative income distribution from 2004 to 2005. 
adjusted to take account of urban-rural price differences in each province. The low income line is much higher than the austere official poverty line of 637 yuan per capita, but at 1112 yuan per capita in 2003 remains significantly lower than the mean dibao line. The other three lines are the \$1/day, \$2/day, and \$3/day poverty lines. The \$1/day line is used by the World Bank for international poverty comparisons, and at 1124 yuan per capita is very close in magnitude to the adjusted low income line. Multiples of the $\$ 1 /$ day line are used to examine how the results change at higher lines. Both the \$2/day and \$3/day lines are higher than the mean dibao line.

Table 2 also presents other poverty lines, including ones used in other studies, for purposes of comparison. The national mean dibao line is very close to the poverty line used by NBS in 2000 and to three times the official rural poverty line. In sections 4 and 5, we use the national mean dibao line to examine in greater detail the determinants of poverty.

\subsection{Poverty Incidence}

Table 3 reports the estimates of poverty incidence across cities when using the different poverty lines. Not surprisingly, estimated poverty rates vary with the chosen poverty line. In large cities, the urban poverty headcount rate ranges from 1.3 percent using the low income line to 9.7 percent using the $\$ 3 /$ day line; in small cities the headcount rates for the same lines are 3.0 percent and 12.0 percent.

Our main focus is comparing the poverty rates of local residents and migrants, and seeing how inclusion of migrants affects overall measures of poverty and inequality. For large cities, the migrant poverty headcount rate of 1.4 percent is slightly higher than the 1.3 percent poverty rate 
of local residents using the adjusted rural low income line. However, at higher poverty lines, the poverty rate of migrants is less than that of local residents. Using the national dibao line, the migrant poverty rate is 2.5 percent compared to 3.2 percent for local residents, and using the \$3/day line, the migrant poverty rate is 9.6 percent compared to 9.8 percent for local residents.

In small cities, the poverty rate of migrants is clearly higher than that of local residents when using low poverty lines. Using the adjusted rural low income line urban households, the poverty headcount rate of migrants is 5.3 percent compared to 2.6 percent for local residents, and using the national dibao line, the poverty headcount rate was 6.2 percent for migrants compared to 5.6 percent for local residents. However, just as for larger cities, as the poverty line increases, migrant poverty rates in small cities become smaller than that of local urban residents. Using the \$3/day line, the poverty headcount rate for migrants is 10.5 percent, compared to 12.4 percent for local residents. Overall the poverty rate differences between migrants and local residents are relatively small, and which is larger depends on which poverty line is chosen.

These differences mask considerable heterogeneity across cities. Table 4 reports the poverty rates for local residents and migrants by city using different poverty lines. Using the national dibao line. In 3 of the 5 large cities and in 4 of 5 small cities, the poverty rate of migrants is higher than that of local residents. ${ }^{7}$ The differences across cities are relatively robust to the poverty line chosen.

To what extent is the relatively low poverty rate of migrants due to the fact that the

\footnotetext{
${ }^{7}$ In the other 2 CULS sample cities, Shenzhen and Daqing, the poverty rates of migrants are also higher than those of local residents.
} 
migrant sample includes both rural and urban migrants? We would expect urban migrants to have higher incomes and lower poverty rates than rural migrants. Table 3 presents poverty rates for the rural migrant sample separately. Since 77 percent of migrants are rural migrants, the poverty rate of migrants is generally very close to the poverty rate of rural migrants. However, it is interesting that in large cities, the poverty rate of rural migrants is actually lower than that of all migrants, implying that rural migrants are less likely to be poor than urban migrants. For small cities, we obtain an opposite result; rural migrants have a higher poverty rate than urban migrants. Using the national mean dibao line, the poverty rate of rural migrants is 2.1 percent compared to 5.1 percent of urban migrants, while for small cities the poverty rate is 6.8 percent for rural migrants and 3.6 percent for urban migrants.

How does the inclusion of migrants affect the measured overall poverty rate in urban areas? Define $P$ to be the urban poverty headcount rate, $P_{M}$ and $P_{L}$ to be the poverty headcount rates for migrants and local residents, respectively, and $R_{M}$ to be the share of migrants in the total urban population. Then, the change in the measured poverty rate associated with the inclusion migrants is the difference between $P$ and $P_{L}$, which can be expressed as follows:

$$
\Delta P=P-P_{L}=\left(P_{M}-P_{L}\right) R_{M}
$$

The impact of migration on the urban poverty rate depends on the difference in the poverty incidences of migrants and local residents and the share of migrants in the population. ${ }^{8}$

\footnotetext{
${ }^{8}$ It is quite easy to develop the formula to the inclusion of both rural migrants and urban migrants. Define $P, P_{L}, P_{R}, P_{U}$ to be the poverty headcount rates of all households, local households, rural migrant households and urban migrant households, respectively; and $R_{R}, R_{U}$ to be the shares of rural migrants and urban migrants in the total urban population, respectively, then changes in urban poverty rate associated with the inclusion of rural migrants
} 
We estimate the share of migrants in the population based on data from the CULS neighborhood surveys, which include questions about the total population and migrant population in each neighborhood. Using this method, migrants account for 16 percent of the total population in the CULS cities surveyed in 2005. This compares to a migrant population share of 26 percent found by the 2000 census in the 2005 CULS sample cities. The difference in shares could reflect sampling biases in the CULS survey if workers living in dormitories or workplaces are systematically under-reported by neighborhood committees. ${ }^{9}$

Given the relatively small differences in estimated poverty rates for migrants and local residents reported in Table 3 and a migrant population share of only 16 percent, it is not surprising that including migrants has a negligible impact on the overall urban poverty estimates (last column of Table 3). Even when we use the higher migrant population shares found in the 2000 census to construct sampling weights, including migrants has little effect on overall poverty rate estimates (results not reported). For example, using the national mean dibao line, there is no change in the urban poverty estimates for either large or small cities. Using the adjusted rural low income line and \$1/day line, there is no change in poverty estimates for large cities, and an increase in the poverty rate from 2.6 to 3.0 percent in small cities. Using the highest poverty line, the \$3/day line, the urban poverty rate decreases from 9.8 percent to 9.7 percent in large cities and from 12.4 percent to 12.0 percent in small cities.

One might be concerned that ignoring the close connection between migrants and their

and urban migrants are $P-P_{L}=\left(P_{R}-P_{L}\right) R_{R}+\left(P_{U}-P_{L}\right) R_{U}$.

${ }^{9}$ In fact, many larger work units do not report their workers to neighborhood committees at all but rather report directly to local Bureaus of Public Security. 
families back home may obscure assessments of their true level of welfare. Specifically, migrants in urban areas could be remitting much of their income to non-coresident family members back home, and so have much less disposable income than we are estimating. There are two ways to address this problem. First, we could focus on consumption-based estimates of the poverty rate. However, because migrants must pay significantly more income to rent housing than local residents, using consumption measures actually increases the status of migrants relative to local residents. Calculating imputed rental values of owner-occupied housing is beyond the scope of this paper, but could yield sharper differences in the welfare of urban residents and migrants.

A second approach is to use income per capita net of private remittances in the poverty calculations. If migrants remit a large share of their incomes to family members living in their hometowns, their own living standard in the city may be adversely affected and they may be more likely to be classified as poor. However, according to the survey data, on average net remittances of rural migrants accounts for only 6.9 percent of their income. This compares to 6.0 percent for urban migrants and 3.9 percent for local residents. Thus, adjusting for remittances only reduces the relative income of migrants compared to local residents by 3.0 percent (6.9 percent minus 3.9 percent). Not surprisingly, this has virtually no effect on the relative poverty rates of local residents and migrants, as seen in Table 5 which presents the same poverty headcount rates as Table 3 but using income per capita net of remittances. Comparing Table 5 to Table 3, we find that none of the previous results are altered. 


\subsection{Depth of Poverty}

Sen (1992) pointed out that the depth of poverty is highly sensitive to the income distribution of the poor. Foster, Greer and Thorbecke (1984) put forward the following normalized formula to calculate poverty indices:

$$
F G T(\alpha)=\frac{1}{N} \sum_{y<z}\left(\frac{z-y}{z}\right)^{\alpha}
$$

Here, $z$ is the poverty line, $y$ is the income of the poor, $z-y$ is the poverty gap, $\frac{z-y}{z}$ is the normalized poverty gap, and $\alpha$ is a parameter that captures aversion to the degree of poverty. FGT (0) is the headcount ratio; FGT (1) is the average normalized poverty gap; and FGT (2) is the average squared normalized poverty gap.

Table 6 presents the poverty gaps using the national mean dibao line as the poverty line. In the 5 large cities, the average normalized poverty gap for local residents, migrants, and all residents are 1.5 percent, 1.3 percent and 1.4 percent, while they are 2.7 percent, 4.6 percent and 3.1 percent in the 5 small cities. The average squared normalized poverty gaps for local residents, migrants, and all residents are all 1.0 percent in the 5 large cities, while they are 2.0 percent, 4.1 percent and 2.4 percent in the 5 small cities. Overall, for large cities inclusion of migrants has little impact on measures of the depth of poverty, similar to the results for poverty incidence. However, for the small cities, the depth of poverty of migrants is significantly higher than that of local residents, so that including migrants increases the poverty gap from 2.7 to 3.1 (14.8 percent), and increases the squared poverty gap from 2.0 percent to 2.4 percent (20.0 percent). This is not surprising in light of the earlier evidence that at low poverty lines, in small 
cities the incidence of poverty was noticeably higher than that of local residents.

\section{Who Are the Urban Poor?}

It may be surprising to some readers that migration does not significantly increase urban poverty. A large part of the explanation can be seen by comparing the characteristics of the migrant population with those of local residents, and considering how these differences result from China’s unique institutional environment.

In Table 7, for migrants and local residents, we summarize the means of key employment variables, including labor force participation, unemployment, hourly wages, and hours worked. The labor force participation rate of adult migrants is 89 percent in large cities and 84 percent in small cities, compared to 56 and 50 percent for adult local residents. Similarly, the unemployment rate of migrants is 1.6 and 4.5 percent in large and small cities, compared to 8.5 and 8.8 percent for local residents. ${ }^{10}$ Finally, migrants on average work 283 hours per month in large cities and 250 hours per month in small cities, compared to 184 and 183 hours per week for local residents. Thus, in large cities, even though mean hourly earnings of migrants is only about a third of that of local residents, the share of adult migrants who work is 75 percent greater than the share of adult local residents who work, and migrants typically work more than 50 percent more hours than local residents. In small cities, the hourly wage differences are much less pronounced but the differences in the other employment variables are similar. Another important difference between migrant and local resident households is that the dependency ratio

\footnotetext{
10 The 2000 census data finds that for all of China, the unemployment rate of migrants was 4.7 percent, while that of local residents was 12.7 percent (Giles, Park, and Zhang, 2005).
} 
(household size divided by number of able workers) is only 1.5 for migrants and 2.1 for local residents (Table 7).

These patterns are consistent with a great deal of self-selection characterizing the migration process. First, rural out-migrants tend to have better human capital than the labor that remains behind in rural areas (Wang, et. al., 2004). Second, in China, all rural households have access to land and are socially connected to their home villages, so that if migrants are unable to find decent-paying jobs in cities, they are likely to return to their family farms. Third, many migrants leave dependents in their home villages, especially if their earnings in the city are insufficient to pay for housing, education, or other costs of living in the city. This means that low-wage earners are less likely to live with dependents, reducing the likelihood of poverty measured on a per capita basis. If a single migrant lives in a work-place dormitory, she only needs to earn 166 yuan per month (including in-kind benefits such as meals) to avoid being poor using the national mean dibao line as the poverty line.

Which households are more likely to be poor? Table 8 summarizes the mean characteristics of non-poor and poor households for both local resident and migrant households. The characteristics correlated with poverty appear to be similar for both local residents and migrants. First, there is no big difference in the distributions of household size between poor and non-poor households. Second, the dependency ratio is significantly higher among the poor. Third, the poor tend to be less educated. For local residents, the poor are much less likely to have a college education, while for migrants the poor are much more likely to have primary school education only. Finally, the work status of the poor is very different than that of the 
nonpoor. Most strikingly, about one fourth of the poor have unemployed workers in their families, compared to just 4.9 percent of non-poor local residents and 1.3 percent of non-poor migrants. The poor are also much more likely to be out of the labor force.

We analyze the determinants of poverty in a multivariate framework by estimating probit models of poverty status for local residents and migrant households separately. Table 9 presents the marginal probabilities that households are found to be poor, once again using the national mean dibao line as the poverty line. Age, education, and employment variables are for the household head. The findings for the most part confirm the descriptive results presented in Table 8. For migrant households, if the household head has a middle school education the probability of being poor falls by 1.1 percent compared to not having completed middle school, if the household head is working the probability of being poor falls by 3.2 percent, and if the household head has an urban hukou the probability of being poor falls by 0.9 percent. Poverty of local resident households is not as responsive to these factors, but is more responsive to household size. Increasing household size by one person reduces the probability of being poor by 0.1 percent. The results also suggest that for both migrants and local residents, being poor is associated with lack of access to social insurance programs.

\section{Urban Income Inequality}

In this section, we examine how migrants affect the overall distribution of income in cities. The simplest way to examine income distributions is to simply plot the empirical distributions. Figure 1 does so for urban and migrant households, separately for large and small 
cities. We see that compared to local residents, the income distribution for migrant households is more tightly concentrated (narrower tails) around a lower mean in the 5 large cities, and is somewhat similar in shape in the 5 small cities except for at the bottom distribution, where it appears that migrants are more likely to be very poor but less likely to have incomes in the range just above the poorest levels.

We can also use Lorenz curves to compare income distributions. As shown in Figure 2, the income Lorenz curves of local resident and migrant households intersect for the 5 large cities, but most of the income Lorenz curve of local residents is below that of migrant households, suggesting that income inequality of local residents is greater than that of migrant households. In contrast, the income Lorenz curve of local residents is above Lorenz curve for migrant households for the 5 small cities, so that income inequality of local residents appears to be smaller than that of migrant households. Compared with rural migrants, the income Lorenz curves of urban migrants are below them in both large cities and small cities. In general, it also appears that income inequality is greater in the small cities than in the large cities.

Table 10 summarizes income inequality of local residents, migrants, and total populations using two commonly used inequality measures--the Gini coefficient and the Theil index. The Gini is more sensitive to changes in the middle of the distribution while the Theil index is more sensitive to changes in the tails of the distribution. Comparing the Gini (Theil) measures of local resident and migrant households, we find that the former is greater than the latter in 3 of 5 large cities, in 2 of 5 ( 1 of 5) small cities, and also in Daqing and Shenzhen. For the 5 large cities combined, the Gini coefficient for local residents is 0.388 , larger than the Gini for migrants 
(0.376). For the 5 small cities, in contrast, the Gini coefficient for local residents (0.404) is lower than that for migrants $(0.481)$. Using the Theil index, inequality is greater for migrants both in large cities and in small cities. Finally, comparing the inequality measures for the total population with that for local residents only, we find that using either the Gini or Theil measures, inequality is greater with the inclusion of migrants. For the large cities, the increase is very slight, while for small cities, the increases are significant (the Gini increases from 0.402 to 0.418 and the Theil index increases from 0.282 to 0.337 ).

The Theil index is one of the generalized entropy (GE) indices, which have the attractive property that they are easily decomposed. Theoretically, a GE index can be additively decomposed into two components: within-group inequality and between-group inequality. It is straightforward to derive the following expression for the change in inequality caused by including migrants in the sample:

$$
\Delta G E=G E-G E_{L}=\left(G E_{M}-G E_{L}\right) * S_{M}+G E_{-} B .^{11}
$$

Here, $G E_{M}$ and $G E_{L}$ are the subgroup income inequality measures for migrant and local resident households, $S_{M}$ is the income share of migrants, and $G E \_B$ is between-group inequality. The impact of migration on the urban income distribution depends on the difference of income inequality among migrants and among local residents, the overall income share of migrant

\footnotetext{
11 Assume $G E \_W$ and $G E \_B$ represent within-group and between-group inequality, $S_{M}$ is the income share of migrants, and $G E_{M}$ and $G E_{L}$ are the subgroup income inequality measures for migrants and local residents. We can decompose urban income inequality as follows: $G E=S_{M} G E_{M}+\left(1-S_{M}\right) G E_{L}+G E \_B$. If $\triangle G E$ is the change in the urban income inequality when migrant households are included in the sample, deriving (2) is straightforward.
} 
households, and the difference in mean incomes of migrants and local residents ${ }^{12}$.

One can see from the first argument in (2) that the similarity in inequality of migrant incomes and local resident incomes leads to little change in overall inequality in large cities when migrants are included, but the greater inequality of migrant incomes in small cities leads to greater inequality in small cities when migrants are included in the sample. Between-group inequality does not appear to contribute significantly to changes in inequality in large cities, even though the mean income per capita of local residents is 27.6 percent greater than that of migrants. In small cities, the mean income per capita of migrants actually is 19.8 percent greater than that of local residents.

\section{Non-income welfare differences}

We next examine differences between local residents and migrants with respect to non-income welfare measures. In recent years, there has been much concern that migrants are discriminated against with respect to access to decent quality housing, access to social insurance and social assistance programs, and access to basic public services such as education (Cai and Wang, 2005). Table 11 describes the housing conditions and access to social insurance programs based on the CULS data. The average area of housing are per capita for migrants was 10.7 square meters, compared to 18.4 square meters for local residents, and migrant housing has much lower rates of provision of drinking water, sewage, and heating. Table 11 also makes clear that migrants have almost no chance of obtaining valuable pension, unemployment

\footnotetext{
${ }^{12}$ We can also develop the above formula to the inclusion of rural migrants and urban migrants separately. In fact, higher income inequality of urban migrants makes a certain contribution to the overall urban income inequality. We do not report this discussion in this paper for the simplicity.
} 
insurance, or health insurance benefits, partly because most work in the private sector where such benefits often are not provided, and partly because of discriminatory policies of local governments. In contrast, most local residents have pension programs and have health insurance. Finally, other research using the CULS data finds that migrants must pay significantly higher school fees for their children if they do not have local hukous. By policy, migrants are not eligible for the urban dibao program or other urban social assistance programs. Overall, it appears that inequality between migrants (especially rural migrants) and local residents in non-income dimensions of welfare are much higher than is reflected in a simple comparison of income per capita levels or income-based poverty measures.

\section{Conclusion}

The main finding of this paper is that based on analysis of recent survey data from the 2005 China Urban Labor Survey in 10 cities, we find that accounting for migrants does not significantly alter income-based estimates of urban poverty and inequality in China. This is not to say that migrants face no problems living and working in cities. Quite to the contrary, studies using the same data find that migrants earn lower wages than local residents after controlling for observable characteristics, and they are much worse off than local residents in terms of a number of important non-income welfare indicators.

The lack of significant income poverty among migrants reflects China's unique institutions, which have enabled migration to be a selective process. Most migrants living in urban areas work long hours and have relatively few dependents living with them in the cities. It 
is not obvious, however, whether such selectivity will persist as migration continues to increase in the future. According to United Nations predictions, 53.2 percent of China's total population will live in cities and townships by 2020. The vast majority (more than 70 percent) of migrants surveyed by the CULS desired to stay in cities, with less than 20 percent of them wanting to return home (Table 12). The survey also found that about one third of migrants definitely expect to live in cities permanently, half report a likelihood of living in cities in the future, and only 15.5 percent expecting not to live in cities (Table 12). The mean duration that surveyed migrants had lived in the city exceeded 9 years in 2005, compared to about 7 years in the first wave of the CULS in 2001. This suggests that the nature of migration in China is quickly shifting from temporary, individual migration to permanent, family-based migration. This could lead to higher rates of unemployment and larger dependency ratios among migrant households in the future, as migration choices become increasingly irreversible.

The survey data suggest that poverty among migrants is not a severe problem in urban areas. However, there exist significant differences between migrants (especially rural migrants) and local residents in access to housing, social insurance programs, social assistance, and public services. As migration becomes increasingly permanent, it will be a great challenge to enable migrant households to become equal members of urban communities. 


\section{References}

Asian Development Bank (ADB), 2002. Urban Poverty in the PRC, Final Report.

Asian Development Bank (ADB), 2004. Poverty Profile of the People's Republic of China.

Brandt, L and C. Holtz, 2005. Spatial price differences in China: estimates and implications, Economics Working Paper Archive EconWPA in its series Development and CompSystems with number 0504010.

Cai, Fang and Dewen Wang, 2005. Impacts of domestic migration on economic growth and urban development in China. Paper Presented at the Conference Migration and Development Within and Across Borders: Concepts, Methods and Policy Considerations in International and Internal Migration, International Organization for Migration (IOM), New York, November 17-19.

Du, Yang, Robert Gregory and Xin Meng, 2006. The impact of the guest-worker system on poverty and the well-being of migrant workers in urban China, in Ross Garnaut and Ligang Song (eds). The Turning Point in China's Economic Development, Asia Pacific Press at the Australian National University, Canberra ACT 0200.

Foster, J.E., J.Greer and Eric Thorbecke, 1984. A class of decomposable poverty measures, Econometrica, Vol.52, pp.761-66.

Giles, John, Albert Park and Fang Cai, 2006. How has economic restructuring affected China's urban workers?,” China Quarterly, 2006, no.185, pp. 61-95.

Giles, John, Albert Park, and Juwei Zhang. "What is China's True Unemployment Rate?” China Economic Review 16: 149-170, 2005.

Hussain, A., 2001. Poverty Profile and Social Security in China, draft report, London School of Economics.

Hussain, A., 2003. Urban Poverty in China: Measurement, Patterns and Policies. International Labour Office, Geneva, January.

Khan, Azizur Rahman, 1998. Poverty in China in the Period of Globalization: New Evidence on Trends and Patterns. Issues in Development Discussion Paper No. 22, Development Policies Department, International Labour Office, Geneva.

$\mathrm{Li}$, Shi, 2001. "Increasing urban poverty at the end of the 1990s and its causes," http://www.cass.net.cn/jingjisuo/yjlw/01.asp?id=194.

Meng, Xin, Robert Gregory, and Youjuan Wang (2005). "Poverty, Inequality, and Growth in Urban China, 1986-2000,” Journal of Comparative Economics 33: 710-729.

Ravallian, Martin, and Shaohua Chen (2007). “China’s (Uneven) Progress Against Poverty,” Journal of Development Economics 82:1-42.

Ren, Caifang and Xiaojie Chen, 1996. "Size, status and trend of poverty in urban China," Research and Reference Materials, No.65.

Sen, Amartya, 1992. Inequality Reexamined, Oxford: Clarendon Press, New York: Russell Sage Foundation, and Cambridge. MA: Harvard University Press.

United Nations Human Settlements Program, 2003. The Challenge of Slums: Global Report on Human Settlements, London: Earthscan Publications and UN-Habitat. 
Wang, Dewen, Yaowu Wu and Fang Cai, 2004. "Migration, unemployment and urban labor market segregation in China's economic transition," The World Economy, No.4.

World Bank, 1992. China: Strategies for Reducing Poverty in the 1990s, Washington D. C.

World Bank, 2009. From Poor Areas to Poor People: China's Evolving Poverty Reduction Agenda (Washington, D.C.: World Bank).. 
Table 1

Basic Information on Surveyed Cities

\begin{tabular}{|c|c|c|c|c|c|c|c|c|}
\hline \multirow[b]{2}{*}{ Cities } & \multicolumn{3}{|c|}{$\begin{array}{c}\text { Number of surveyed } \\
\text { households }\end{array}$} & \multicolumn{3}{|c|}{$\begin{array}{c}\text { Number of surveyed } \\
\text { individuals }\end{array}$} & \multirow{2}{*}{$\begin{array}{c}\text { Total } \\
\text { population } \\
\text { (million) }\end{array}$} & \multirow{2}{*}{$\begin{array}{c}\text { Per capita } \\
\text { income } \\
\text { (Yuan) }\end{array}$} \\
\hline & $\begin{array}{l}\text { Local } \\
\text { residents }\end{array}$ & Migrants & $\begin{array}{c}\text { Rural } \\
\text { migrants }\end{array}$ & $\begin{array}{c}\text { Local } \\
\text { residents }\end{array}$ & Migrants & $\begin{array}{c}\text { Rural } \\
\text { migrants }\end{array}$ & & \\
\hline Large cities & 2500 & 2514 & 2041 & 7485 & 5618 & 4680 & 42.3 & 11263 \\
\hline Shanghai & 500 & 500 & 360 & 1440 & 1034 & 743 & 13.5 & 16683 \\
\hline Wuhan & 500 & 503 & 434 & 1621 & 1253 & 1109 & 7.9 & 9564 \\
\hline Shenyang & 494 & 494 & 373 & 1379 & 982 & 777 & 6.9 & 8924 \\
\hline Fuzhou & 497 & 506 & 450 & 1545 & 1173 & 1058 & 6.6 & 11516 \\
\hline Xian & 509 & 511 & 424 & 1500 & 1176 & 993 & 7.4 & 9628 \\
\hline Small cities & 2323 & 1999 & 1614 & 7179 & 4848 & 4043 & 5.7 & 9763 \\
\hline Wuxi & 500 & 402 & 286 & 1496 & 994 & 771 & 2.2 & 11647 \\
\hline Yichan & 400 & 404 & 309 & 1208 & 973 & 770 & 1.2 & 7033 \\
\hline Benxi & 523 & 400 & 345 & 1604 & 999 & 880 & 1.0 & 6347 \\
\hline Zhuhai & 500 & 390 & 290 & 1662 & 987 & 773 & 0.8 & 16602 \\
\hline Baoji & 400 & 403 & 384 & 1209 & 895 & 849 & 0.6 & 7049 \\
\hline
\end{tabular}

Note: (1) Figures of total population, per capita GDP and per capita disposable income in each city are from their 2005 statistical yearbooks. (2) Per capita GDP and per capita disposable income are the arithmetic average values in the rows of five large cities, five small cities and total. 
Table 2

China Urban Poverty Lines

2003 yuan

Poverty lines used in analysis

Adjusted rural low income line

1112

World Bank \$1/day

1124

National mean dibao line

1982

World Bank \$2/day

2247

World Bank \$3/day

3371

Other poverty lines

Official rural poverty line (2003)

637

Twice the official rural poverty line (2003)

1274

DRC poverty line (1997) ${ }^{1}$

1691

Khan (1995) ${ }^{1}$

1790

MOCA poverty line (1999) ${ }^{1}$

1825

Triple the official rural poverty line (2003)

1911

NBS poverty line (2000) ${ }^{1}$

1948

${ }^{1}$ Reported in ADB (2004). 
Table 3

Urban Poverty Incidence of Local Residents and Migrants (\%)

\begin{tabular}{lcccc}
\hline & $\begin{array}{c}\text { Urban local } \\
\text { residents }\end{array}$ & Migrants & $\begin{array}{c}\text { Rural } \\
\text { migrants }\end{array}$ & All \\
\hline Large cities & & & & \\
$\quad$ Adjusted rural low income line & 1.3 & 1.4 & 1.3 & 1.3 \\
\$1/day & 1.4 & 1.4 & 1.3 & 1.4 \\
$\quad$ National mean dibao line & 3.2 & 2.5 & 2.1 & 3.2 \\
\$2/day & 3.8 & 3.3 & 3.0 & 3.8 \\
\$3/day & 9.8 & 9.6 & 9.7 & 9.7 \\
Small cities & & & & \\
$\quad$ Adjusted rural low income line & 2.6 & 5.3 & 5.8 & 3.0 \\
\$1/day & 2.6 & 5.3 & 5.8 & 3.0 \\
National mean dibao line & 5.6 & 6.2 & 6.8 & 5.7 \\
\$2/day & 6.6 & 6.6 & 7.3 & 6.6 \\
\$3/day & 12.4 & 10.5 & 12.0 & 12.0 \\
\hline
\end{tabular}


Table 4

Urban Poverty Incidence by City

\begin{tabular}{|c|c|c|c|c|c|c|c|c|c|}
\hline \multirow[b]{2}{*}{ City } & \multicolumn{3}{|c|}{ Adjusted rural low income line } & \multicolumn{3}{|c|}{ National mean dibao line } & \multicolumn{3}{|c|}{ \$3/day } \\
\hline & $\begin{array}{c}\text { Local } \\
\text { residents }\end{array}$ & Migrants & All & $\begin{array}{c}\text { Local } \\
\text { residents }\end{array}$ & Migrants & All & $\begin{array}{c}\text { Local } \\
\text { residents }\end{array}$ & Migrants & All \\
\hline \multicolumn{10}{|l|}{ Large cities } \\
\hline Shanghai & 0.4 & 0.7 & 0.4 & 0.6 & 0.7 & 0.6 & 1.4 & 3.8 & 3.5 \\
\hline Wuhan & 1.8 & 1.3 & 1.8 & 5.2 & 4.5 & 5.1 & 18.9 & 19.7 & 15.9 \\
\hline Shenyang & 1.5 & 5.1 & 1.6 & 4.7 & 5.9 & 4.8 & 9.7 & 12.2 & 14.8 \\
\hline Fuzhou & 0.3 & 2.4 & 0.5 & 1.3 & 2.8 & 1.4 & 5.6 & 8.4 & 1.6 \\
\hline Xian & 2.9 & 1.3 & 2.5 & 5.4 & 2.3 & 4.7 & 15.8 & 8.1 & 14.3 \\
\hline \multicolumn{10}{|l|}{ Small cities } \\
\hline Wuxi & 1.2 & 3.4 & 1.5 & 1.9 & 4.0 & 2.1 & 4.0 & 6.6 & 1.3 \\
\hline Yichan & 4.9 & 7.5 & 5.0 & 12.9 & 17.3 & 13.1 & 29.1 & 38.6 & 17.6 \\
\hline Benxi & 1.2 & 5.3 & 1.2 & 2.6 & 11.5 & 2.7 & 7.1 & 33.8 & 47.5 \\
\hline Zhuhai & 5.0 & 6.2 & 5.5 & 8.4 & 6.2 & 7.4 & 13.5 & 9.2 & 4.4 \\
\hline Baoji & 1.7 & 0.2 & 1.7 & 5.0 & 3.3 & 4.9 & 15.1 & 23.2 & 31.7 \\
\hline
\end{tabular}


Table 5

Net Remittances by Urban Local Residents and Migrants

\begin{tabular}{lcccc}
\hline & $\begin{array}{c}\text { Sample } \\
\text { size }\end{array}$ & $\begin{array}{c}\text { Mean income per } \\
\text { capita before } \\
\text { remittance (yuan) } \\
(1)\end{array}$ & $\begin{array}{c}\text { Mean net } \\
\text { remittance per } \\
\text { capita (yuan) } \\
(2)\end{array}$ & $\begin{array}{c}\text { Net remittance } \\
\text { share of income } \\
(\%) \\
(1) /(2)\end{array}$ \\
\hline Urban local residents & 6324 & 12242 & 472 & 3.86 \\
Urban migrants & 1341 & 17912 & 1066 & 5.95 \\
Rural migrants & 4179 & 8842 & 614 & 6.94 \\
\hline
\end{tabular}

Table 5

Urban Poverty Incidence Using Income Per Capita Net of Remittances (\%)

\begin{tabular}{lcccc}
\hline City & $\begin{array}{c}\text { Local } \\
\text { residents }\end{array}$ & Migrants & $\begin{array}{c}\text { Rural } \\
\text { migrants }\end{array}$ & All \\
\hline Large cities & & & & \\
$\quad$ Adjusted rural low income line & 1.6 & 1.5 & 1.4 & 1.6 \\
$\quad$ \$1/day & 1.6 & 1.5 & 1.4 & 1.6 \\
$\quad$ National mean dibao line & 3.6 & 3.3 & 3.0 & 3.5 \\
\$2/day & 4.2 & 4.5 & 4.3 & 4.2 \\
\$3/day & 10.3 & 13.0 & 13.4 & 10.6 \\
Small cities & & & & \\
Adjusted rural low income line & 3.4 & 5.6 & 6.0 & 3.8 \\
\$1/day & 3.4 & 5.6 & 6.0 & 3.8 \\
National mean dibao line & 6.9 & 6.6 & 7.2 & 6.8 \\
\$2/day & 8.2 & 6.9 & 7.6 & 8.0 \\
\$3/day & 14.8 & 12.0 & 13.4 & 14.3 \\
\hline
\end{tabular}


Table 6

Depth of Poverty

\begin{tabular}{|c|c|c|c|c|c|}
\hline City & $\begin{array}{c}\text { Urban local } \\
\text { residents }\end{array}$ & Migrants & Rural migrants & Urban migrants & All \\
\hline & \multicolumn{5}{|c|}{ Average normalized poverty gap $(* 100)$} \\
\hline Large cities & 1.5 & 1.3 & 1.1 & 2.0 & 1.4 \\
\hline Shanghai & 0.4 & 0.7 & 0.7 & 0.6 & 0.5 \\
\hline Wuhan & 2.2 & 2.0 & 2.0 & 2.0 & 2.2 \\
\hline Shenyang & 1.8 & 5.2 & 4.2 & 9.3 & 1.9 \\
\hline Fuzhou & 0.4 & 2.5 & 2.6 & 1.5 & 0.5 \\
\hline Xian & 2.8 & 0.8 & 0.5 & 3.5 & 2.3 \\
\hline Small cities & 2.7 & 4.6 & 5.0 & 3.1 & 3.1 \\
\hline Wuxi & 1.3 & 3.1 & 3.7 & 0.9 & 1.5 \\
\hline Yichan & 5.6 & 8.2 & 8.7 & 5.4 & 5.7 \\
\hline Benxi & 1.0 & 5.6 & 5.2 & 8.2 & 1.1 \\
\hline Zhuhai & 5.3 & 5.1 & 5.4 & 3.8 & 5.2 \\
\hline \multirow[t]{2}{*}{ Baoji } & 1.8 & 0.8 & 0.9 & 0.0 & 1.7 \\
\hline & \multicolumn{5}{|c|}{ Average squared normalized poverty gap $(* 100)$} \\
\hline Large cities & 1.0 & 1.0 & 0.9 & 1.6 & 1.0 \\
\hline Shanghai & 0.4 & 0.6 & 0.7 & 0.5 & 0.4 \\
\hline Wuhan & 1.3 & 1.5 & 1.5 & 1.3 & 1.3 \\
\hline Shenyang & 1.1 & 5.0 & 4.1 & 9.1 & 1.2 \\
\hline Fuzhou & 0.3 & 2.4 & 2.5 & 1.3 & 0.5 \\
\hline Xian & 2.1 & 0.4 & 0.2 & 2.4 & 1.7 \\
\hline Small cities & 2.0 & 4.1 & 4.4 & 2.9 & 2.4 \\
\hline Wuxi & 1.1 & 2.9 & 3.4 & 0.9 & 1.3 \\
\hline Yichan & 3.9 & 6.8 & 7.1 & 5.0 & 4.0 \\
\hline Benxi & 0.6 & 5.1 & 4.6 & 8.1 & 0.6 \\
\hline Zhuhai & 4.3 & 4.4 & 4.7 & 3.4 & 4.3 \\
\hline Baoji & 1.1 & 1.9 & 2.0 & 0.0 & 1.2 \\
\hline
\end{tabular}


Table 7

Labor Participation Rate, Unemployment Rate, Working Hours and Hourly Wages

\begin{tabular}{lcccc}
\hline & Local residents & Migrants & Rural migrants & Urban migrants \\
\hline $\begin{array}{l}\text { Labor force participation rate } \\
\text { Large cities }\end{array}$ & 56.1 & 89.3 & 89.6 & 87.9 \\
$\quad$ Small cities & 50.1 & 84.0 & 84.7 & 81.3 \\
Unemployment rate & & & & \\
$\quad$ Large cities & 8.5 & 1.6 & 1.3 & 3.0 \\
$\quad$ Small cities & 8.8 & 4.5 & 5.1 & 2.4 \\
Hourly wages & & & & \\
$\quad$ Large cities & 14.7 & 4.6 & 4.1 & 7.1 \\
$\quad$ Small cities & 8.3 & 7.6 & 6.1 & 13.1 \\
Working hours & & & & \\
Large cities & 182.7 & 282.9 & 287.7 & 258.3 \\
$\quad$ Small cities & 184.0 & 250.0 & 253.2 & 238.8 \\
\hline
\end{tabular}

Table 8

Characteristics of Non-Poor and Poor Households

\begin{tabular}{lccccccccccc}
\hline & \multicolumn{1}{c}{ Urban households } & \multicolumn{4}{c}{ Migrant households } & \multicolumn{4}{c}{$\begin{array}{c}\text { Rural migrant } \\
\text { households }\end{array}$} \\
& Nonpoor & Poor & All & Nonpoor Poor & All & Nonpoor Poor & All \\
\hline $\begin{array}{l}\text { Dependency ratio } \\
\text { Education }\end{array}$ & 2.1 & 2.9 & 2.1 & 1.5 & 2.0 & 1.5 & 1.5 & 2.0 & 1.5 \\
$\quad$ & & & & & & & & & \\
$\quad \begin{array}{l}\text { Primary and below } \\
\text { Middle school }\end{array}$ & 3.4 & 4.8 & 3.5 & 17.1 & 27.6 & 17.5 & 20.2 & 36.4 & 20.8 \\
$\quad$ High school & 26.6 & 41.9 & 27.2 & 48.5 & 45.1 & 48.4 & 53.6 & 50.0 & 53.5 \\
$\quad$ College and above & 34.6 & 37.0 & 34.7 & 21.6 & 15.6 & 21.3 & 19.3 & 9.8 & 19.0 \\
Working status & 35.4 & 16.2 & 34.6 & 12.8 & 11.7 & 12.8 & 6.9 & 3.7 & 6.8 \\
$\quad$ Employed & & & & & & & & & \\
$\quad$ Unemployed & 61.8 & 21.2 & 60.1 & 85.6 & 36.0 & 83.6 & 86.9 & 37.1 & 85.2 \\
$\quad$ Non-working & 4.9 & 25.7 & 5.7 & 1.3 & 25.4 & 2.3 & 1.1 & 27.3 & 2.0 \\
\hline
\end{tabular}


Table 9

Probit Model of Household Poverty Status (Marginal Probabilities)

\begin{tabular}{|c|c|c|c|c|}
\hline & $\begin{array}{c}\text { Local } \\
\text { resident } \\
\text { households }\end{array}$ & $\begin{array}{c}\text { Migrant } \\
\text { households }\end{array}$ & $\begin{array}{c}\text { Rural migrant } \\
\text { households }\end{array}$ & $\begin{array}{c}\text { Urban } \\
\text { migrant } \\
\text { households }\end{array}$ \\
\hline \multicolumn{5}{|l|}{ Household head characteristics } \\
\hline Male & $\begin{array}{l}0.003 \\
(2.31)^{*}\end{array}$ & $\begin{array}{c}0.017 \\
(5.85)^{* *}\end{array}$ & $\begin{array}{c}0.008 \\
(2.78) * *\end{array}$ & $\begin{array}{c}0.022 \\
(4.60)^{* *}\end{array}$ \\
\hline Age 16-29 & $\begin{array}{l}-0.005 \\
(1.68)\end{array}$ & $\begin{array}{r}-0.001 \\
(0.23)\end{array}$ & $\begin{array}{r}-0.002 \\
(0.85)\end{array}$ & $\begin{array}{c}0.002 \\
(0.54)\end{array}$ \\
\hline Age $40-49$ & $\begin{array}{c}0.004 \\
(1.99)^{*}\end{array}$ & $\begin{array}{l}0.004 \\
(1.39)\end{array}$ & $\begin{array}{l}0.004 \\
(1.47)\end{array}$ & $\begin{array}{l}0.007 \\
(1.19)\end{array}$ \\
\hline Age 50-59 & $\begin{array}{c}-0.006 \\
(3.71)^{* *}\end{array}$ & $\begin{array}{l}0.000 \\
(0.13)\end{array}$ & $\begin{array}{l}-0.004 \\
(1.27)\end{array}$ & $\begin{array}{l}0.011 \\
(1.44)\end{array}$ \\
\hline Age 60 and above & $\begin{array}{c}-0.012 \\
(7.24)^{* *}\end{array}$ & $\begin{array}{l}0.020 \\
(1.80)\end{array}$ & $\begin{array}{c}0.049 \\
(2.40)^{*}\end{array}$ & $\begin{array}{l}-0.000 \\
(0.05)\end{array}$ \\
\hline Middle school & $\begin{array}{c}-0.000 \\
(0.12)\end{array}$ & $\begin{array}{c}-0.011 \\
(4.57)^{* *}\end{array}$ & $\begin{array}{c}-0.010 \\
(4.56)^{* *}\end{array}$ & $\begin{array}{l}0.011 \\
(1.06)\end{array}$ \\
\hline High school & $\begin{array}{l}-0.003 \\
(1.39)\end{array}$ & $\begin{array}{r}-0.002 \\
(0.58)\end{array}$ & $\begin{array}{c}-0.008 \\
(2.18)^{*}\end{array}$ & $\begin{array}{l}0.033 \\
(1.85)\end{array}$ \\
\hline College and above & $\begin{array}{l}-0.005 \\
(1.93)\end{array}$ & $\begin{array}{l}-0.004 \\
(0.92)\end{array}$ & $\begin{array}{l}-0.004 \\
(0.83)\end{array}$ & $\begin{array}{l}0.020 \\
(1.39)\end{array}$ \\
\hline Working & $\begin{array}{c}-0.008 \\
(3.39)^{* *}\end{array}$ & $\begin{array}{c}-0.032 \\
(7.20)^{* *}\end{array}$ & $\begin{array}{c}-0.036 \\
(6.26)^{* *}\end{array}$ & $\begin{array}{l}-0.042 \\
(2.54)^{*}\end{array}$ \\
\hline Nonworking & $\begin{array}{c}-0.006 \\
(2.34)^{*}\end{array}$ & $\begin{array}{r}-0.001 \\
(0.19)\end{array}$ & $\begin{array}{c}-0.019 \\
(3.20)^{* *}\end{array}$ & $\begin{array}{l}0.005 \\
(1.02)\end{array}$ \\
\hline Hukou & $\begin{array}{l}0.008 \\
(0.94)\end{array}$ & $\begin{array}{c}-0.009 \\
(3.69)^{* *}\end{array}$ & $\begin{array}{l}-0.000 \\
(0.01)\end{array}$ & $\begin{array}{l}-0.004 \\
(0.70)\end{array}$ \\
\hline $\begin{array}{l}\text { Share of labor with high school } \\
\text { education or above }\end{array}$ & 0.000 & -0.000 & -0.000 & -0.000 \\
\hline & $(0.75)$ & $(2.90) * *$ & $(0.98)$ & $(1.94)$ \\
\hline Share of labor employed & $\begin{array}{c}-0.000 \\
(9.32)^{* *}\end{array}$ & $\begin{array}{c}-0.000 \\
(6.96)^{* *}\end{array}$ & $\begin{array}{c}-0.000 \\
(7.00)^{* *}\end{array}$ & $\begin{array}{c}-0.000 \\
(4.13)^{* *}\end{array}$ \\
\hline Unemployed labor & $\begin{array}{c}0.004 \\
(1.67)\end{array}$ & $\begin{array}{c}0.026 \\
(4.17)^{* *}\end{array}$ & $\begin{array}{c}0.003 \\
(0.52)\end{array}$ & $\begin{array}{c}0.027 \\
(2.71)^{* *}\end{array}$ \\
\hline Household receives pension & $\begin{array}{c}-0.011 \\
(4.29)^{* *}\end{array}$ & $\begin{array}{c}-0.011 \\
(4.14)^{* *}\end{array}$ & $\begin{array}{c}-0.009 \\
(3.82)^{* *}\end{array}$ & $\begin{array}{l}-0.009 \\
(2.41)^{*}\end{array}$ \\
\hline
\end{tabular}




\begin{tabular}{|c|c|c|c|c|}
\hline \multirow{2}{*}{$\begin{array}{l}\text { Household receives } \\
\text { unemployment insurance }\end{array}$} & 0.003 & -0.010 & -0.007 & -0.008 \\
\hline & $(1.77)$ & $(2.96)^{* *}$ & $(2.01)^{*}$ & $(1.38)$ \\
\hline \multirow[t]{2}{*}{ Household has health insurance } & -0.008 & 0.026 & 0.112 & 0.001 \\
\hline & $(3.85)^{* *}$ & $(3.34)^{* *}$ & $(4.67)^{* *}$ & $(0.30)$ \\
\hline \multirow[t]{2}{*}{ Household size } & -0.001 & -0.004 & -0.004 & -0.003 \\
\hline & $(1.08)$ & $(3.76)^{* *}$ & $(3.87)^{* *}$ & $(2.15)^{*}$ \\
\hline \multirow[t]{2}{*}{ Wuhan } & 0.024 & 0.071 & 0.034 & 0.107 \\
\hline & $(5.09)^{* *}$ & $(4.70)^{* *}$ & $(3.08)^{* *}$ & $(2.94)^{* *}$ \\
\hline \multirow[t]{2}{*}{ Shenyang } & 0.028 & 0.077 & 0.023 & 0.265 \\
\hline & $(4.52)^{* *}$ & $(3.58)^{* *}$ & $(1.72)$ & $(3.55)^{* *}$ \\
\hline \multirow[t]{2}{*}{ Fuzhou } & 0.015 & 0.055 & 0.028 & 0.084 \\
\hline & $(1.91)$ & $(2.63)^{* *}$ & $(1.90)$ & $(0.90)$ \\
\hline \multirow[t]{2}{*}{ Xian } & 0.040 & 0.019 & 0.001 & 0.148 \\
\hline & $(5.76)^{* *}$ & $(2.43)^{*}$ & $(0.11)$ & $(3.61)^{* *}$ \\
\hline \multirow[t]{2}{*}{ Daqing } & 0.165 & 0.146 & 0.086 & 0.200 \\
\hline & $(2.88)^{* *}$ & $(5.65)^{* *}$ & $(4.12)^{* *}$ & $(3.45)^{* *}$ \\
\hline \multirow[t]{2}{*}{ Wuxi } & 0.078 & 0.067 & 0.038 & 0.014 \\
\hline & $(2.14)^{*}$ & $(3.93)^{* *}$ & $(2.86)^{* *}$ & $(0.64)$ \\
\hline \multirow[t]{2}{*}{ Yichan } & 0.250 & 0.253 & 0.156 & 0.090 \\
\hline & $(3.47)^{* *}$ & $(5.78)^{* *}$ & $(4.42)^{* *}$ & $(1.26)$ \\
\hline \multirow[t]{2}{*}{ Benxi } & 0.051 & 0.072 & 0.031 & 0.039 \\
\hline & (1.62) & $(1.50)$ & $(0.96)$ & $(0.31)$ \\
\hline \multirow[t]{2}{*}{ Zhuhai } & 0.118 & 0.071 & 0.034 & 0.113 \\
\hline & $(2.47)^{*}$ & $(4.64)^{* *}$ & $(2.99)^{* *}$ & $(3.05)^{* *}$ \\
\hline \multirow[t]{2}{*}{ Baoji } & 0.140 & 0.096 & 0.055 & \\
\hline & $(2.58)^{* *}$ & (1.81) & (1.44) & \\
\hline \multirow[t]{2}{*}{ Shenzhen } & 0.022 & 0.032 & 0.010 & 0.040 \\
\hline & (1.14) & $(3.31)^{* *}$ & (1.35) & $(3.02)^{* *}$ \\
\hline Observations & 6298 & 5453 & 4152 & 1276 \\
\hline
\end{tabular}

Note: Absolute value of z statistics in parentheses;* significant at $5 \%$; ** significant at $1 \%$ 
Table 10

Income Inequality by City

\begin{tabular}{|c|c|c|c|c|c|}
\hline City & $\begin{array}{c}\text { Urban local } \\
\text { residents }\end{array}$ & Migrants & Rural migrants & Urban migrants & All \\
\hline & \multicolumn{5}{|c|}{ Gini coefficient } \\
\hline Large cities & 0.388 & 0.376 & 0.347 & 0.439 & 0.389 \\
\hline Shanghai & 0.314 & 0.373 & 0.351 & 0.398 & 0.320 \\
\hline Wuhan & 0.368 & 0.351 & 0.340 & 0.358 & 0.368 \\
\hline Shenyang & 0.364 & 0.397 & 0.336 & 0.453 & 0.366 \\
\hline Fuzhou & 0.342 & 0.319 & 0.318 & 0.293 & 0.344 \\
\hline Xian & 0.361 & 0.329 & 0.302 & 0.514 & 0.354 \\
\hline Small cities & 0.404 & 0.481 & 0.403 & 0.572 & 0.418 \\
\hline Wuxi & 0.359 & 0.541 & 0.352 & 0.687 & 0.387 \\
\hline Yichan & 0.412 & 0.497 & 0.460 & 0.529 & 0.417 \\
\hline Benxi & 0.287 & 0.392 & 0.365 & 0.489 & 0.289 \\
\hline Zhuhai & 0.447 & 0.425 & 0.412 & 0.414 & 0.448 \\
\hline \multirow[t]{2}{*}{ Baoji } & 0.344 & 0.299 & 0.294 & 0.289 & 0.344 \\
\hline & \multicolumn{5}{|c|}{ Theil Index } \\
\hline Large cities & 0.249 & 0.253 & 0.204 & 0.351 & 0.252 \\
\hline Shanghai & 0.163 & 0.246 & 0.209 & 0.291 & 0.169 \\
\hline Wuhan & 0.233 & 0.198 & 0.182 & 0.219 & 0.232 \\
\hline Shenyang & 0.228 & 0.267 & 0.202 & 0.272 & 0.229 \\
\hline Fuzhou & 0.193 & 0.160 & 0.158 & 0.156 & 0.195 \\
\hline Xian & 0.210 & 0.201 & 0.150 & 0.525 & 0.208 \\
\hline Small cities & 0.282 & 0.596 & 0.309 & 0.890 & 0.337 \\
\hline Wuxi & 0.233 & 0.857 & 0.189 & 1.153 & 0.328 \\
\hline Yichan & 0.271 & 0.568 & 0.480 & 0.624 & 0.284 \\
\hline Benxi & 0.149 & 0.249 & 0.219 & 0.362 & 0.151 \\
\hline Zhuhai & 0.315 & 0.374 & 0.349 & 0.363 & 0.348 \\
\hline Baoji & 0.186 & 0.150 & 0.147 & 0.147 & 0.187 \\
\hline
\end{tabular}


Table 11

Comparison of Housing Conditions and Social Insurance Coverage of Local Residents and Migrants

\begin{tabular}{lcccc}
\hline & $\begin{array}{c}\text { Local } \\
\text { resident } \\
\text { workers }\end{array}$ & $\begin{array}{c}\text { Migrant } \\
\text { workers }\end{array}$ & $\begin{array}{c}\text { Rural } \\
\text { migrant } \\
\text { workers }\end{array}$ & $\begin{array}{c}\text { Urban } \\
\text { migrant } \\
\text { workers }\end{array}$ \\
\hline $\begin{array}{l}\text { Housing conditions (5 large cities) } \\
\quad \text { Construction areas (square meters) }\end{array}$ & 18.4 & 10.7 & 9.9 & 15.2 \\
$\quad$ Has drinking water (\%) & 98.8 & 78.1 & 75.1 & 94.1 \\
$\quad$ Has toilet (\%) & 88.2 & 45.5 & 40.4 & 73.2 \\
$\quad$ Has heating (\%) & 61.7 & 31.8 & 27.4 & 54.8 \\
Pension (\%) & & & & \\
$\quad$ Large cities & 61.0 & 5.7 & 2.7 & 20.9 \\
$\quad$ Small cities & 65.5 & 16.2 & 10.8 & 34.7 \\
Unemployment insurance (\%) & & & & \\
$\quad$ Large cities & 17.6 & 1.8 & 1.3 & 4.1 \\
$\quad$ Small cities & 25.0 & 12.4 & 8.7 & 25.3 \\
Medical insurance (\%) & & & & \\
$\quad$ Large cities & 50.7 & 3.9 & 1.8 & 14.4 \\
$\quad$ Small cities & 61.0 & 15.8 & 11.1 & 31.8 \\
\hline
\end{tabular}

Table 12

Migrants' Residential Mobility

\begin{tabular}{lcccccc}
\hline & \multicolumn{3}{c}{ Preferred future location } \\
& Stay in & Return & $\begin{array}{c}\text { Love to } \\
\text { another }\end{array}$ & & & Definitely \\
City & city & home & place & Definitely & Possibly & not \\
\hline Large cities & 72.3 & 19.6 & 8.1 & 37.0 & 46.3 & 16.8 \\
Small cities & 77.7 & 16.8 & 5.5 & 29.5 & 56.3 & 14.2 \\
\hline
\end{tabular}


Figure 1 Income Distribution of Urban and Migrant Households by City Type
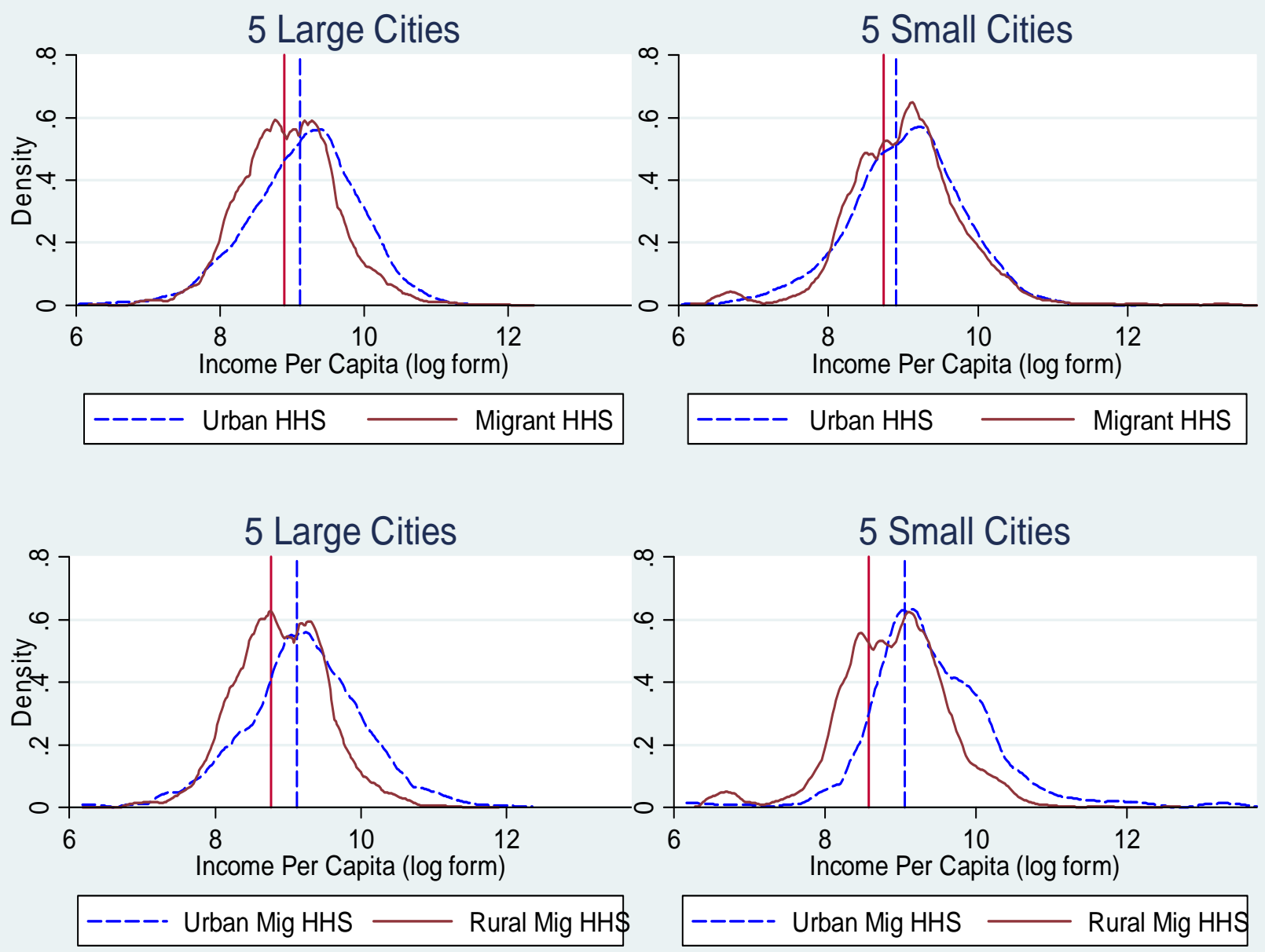
Figure 2 Income Lorenz Curves of Urban and Migrant Households by City Type
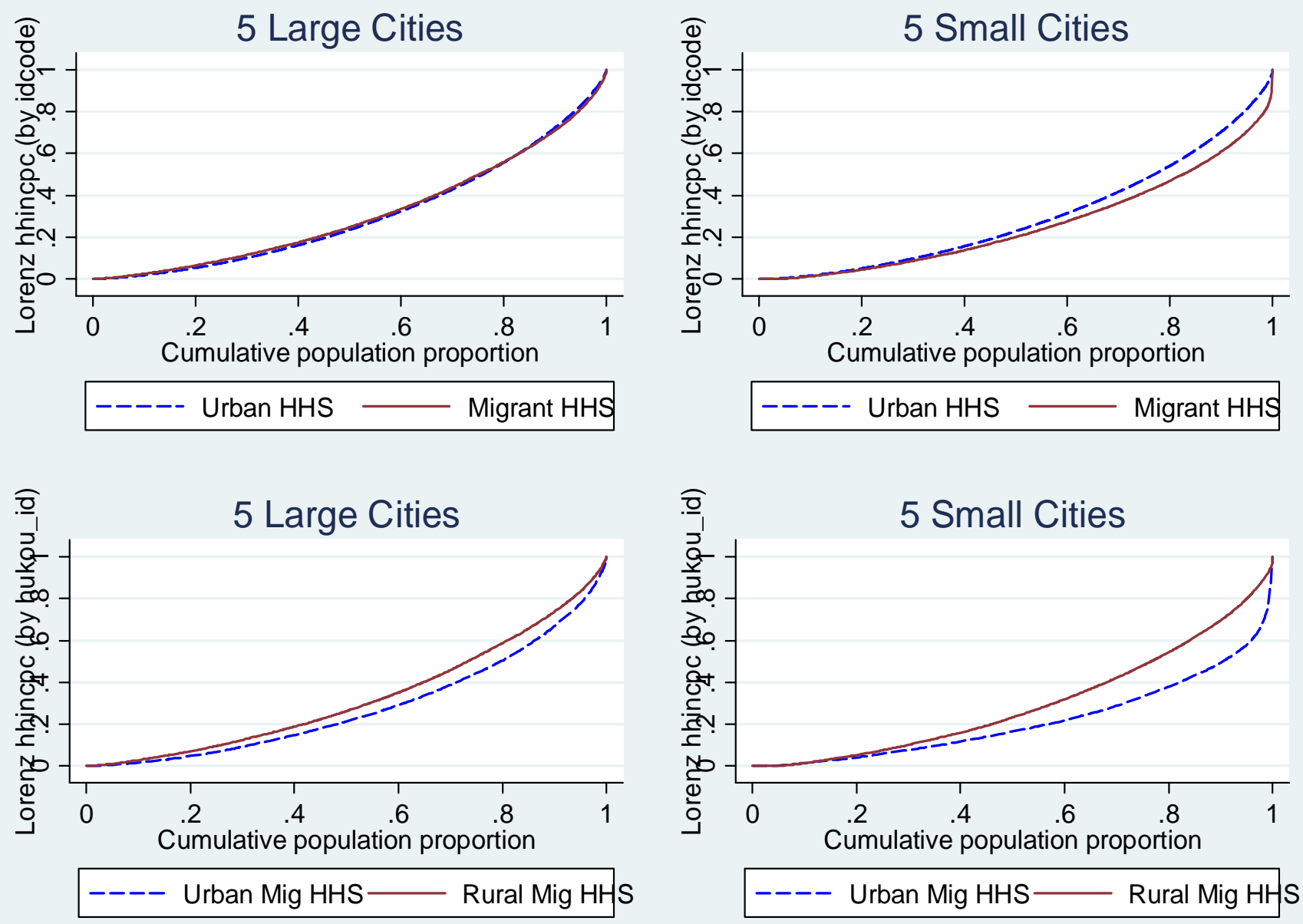